\title{
Ecophysiological responses to the effect of annual management on an endemic viviparous fish in central plateau of México
}

\author{
Fernando Garcia-Trejo ${ }^{1}$, Silvia Laura Hurtado-Gonzalez ${ }^{1}$, Genaro Soto-Zarazúa ${ }^{1}$, \\ Oscar Alatorre-Jacome ${ }^{1}$, Enrique Rico-García and Pedro Joaquín Gutiérrez-Yurrita²
}

Studies on the biological aspects of fish typically focus on species that currently have commercial value, causing species that lack such market value to be ignored. This is the case of several freshwater fish, specifically of several members of the Goodeidae family. In the State of Querétaro there are several species of this family characterized for being viviparous and having distinctive sexual dimorphism that may have commercial potential. The subject of this study is Girardinichthys multiradiatus, a viviparous fish endemic to the upper-half of the Lerma River basin. The lack of knowledge regarding its biology and ecology has prevented the development of guidelines to manage its habitat and to preserve its population. The objective was to determine the ecophysiological responses of G. multiradiatus to its environmental management. From the sampling (24 hours every two months) population structure and dynamics were analyzed throughout a hydrological cycle using meristic data (standard length). Trophic and ecophysiological responses to fluctuations in environmental factors were also identified. Although the mexcalpique is a polytrophic species, results show that it prefers feeding on Diptera or Cladocera, while detritus is the third substance frequently found in their stomachs. Environmentally, the water regime is responsible for fluctuations in the population dynamics of the species, while temperature changes are the most influence its energy balance. These results can guide efforts to conserve this species and its habitat.

Los estudios sobre aspectos biológicos de los peces se centran, generalmente, en especies que actualmente tienen interés comercial, lo que ocasiona que las especies que carecen de tal valor en el mercado estén prácticamente olvidadas; tal es el caso de varios peces de agua dulce y más específicamente de algunos integrantes de la familia Godeidae. En el estado de Querétaro se encuentran varias especies pertenecientes a esta familia que se caracterizan por ser vivíparas y presentar un marcado dimorfismo sexual, aspectos que pudieran definir un potencial comercial. El pez objeto de este estudio es Girardinichthys multiradiatus, especie endémica de la parte alta-media de la cuenca del río Lerma; los lugares donde habita presentan procesos de degradación, fragmentación del hábitat y extracción de agua, que ponen en riesgo su existencia. Además, la falta de conocimiento sobre su biología y ecología, no permiten que se elaboren pautas de gestión de sus poblaciones o hábitats con fines de conservación y preservación de la especie o de los procesos ecológicos que mantienen la estabilidad del ecosistema que ocupa. En el presente trabajo se estudió la población de G. multiradiatus localizada en el bordo de San Martín, Amealco. El objetivo del presente trabajo fue determinar las respuestas ecofisológicas de G. multiradiatus debido al manejo de su ambiente. Se hicieron ciclos de 24 horas en muestreos bimensuales a lo largo de un ciclo hidrológico en el que se analizaron la estructura y dinámica de la población; asimismo, se determinaron las respuestas tróficas y ecofisiológicas de la población ante las fluctuaciones de los factores ambientales de su entorno. Los resultados muestran que aunque el mexcalpique es polítrofo, prefiere dípteros, cladóceros y detritus, habiendo diferencias alimentarias entre las clases de edades. G. multiradiatus presenta 12 clases de talla que van de 8 a $48 \mathrm{~mm}$ de longitud patrón. En el medio ambiente, el régimen de agua es responsable de las fluctuaciones en la dinámica poblacional de las especies, mientras que el cambio de temperatura es el factor de mayor influencia sobre su balance energético. Estos resultados pueden guiar los esfuerzos para conservar esta especie y su hábitat.

Key words: Bioenergetics, Conservation, Deterioration, Population dynamic, Trophic spectrum.

\footnotetext{
${ }^{1}$ División de Investigación y Posgrado, Facultad de Ingeniería, Universidad Autónoma de Querétaro, Centro Universitario, Cerro de las Campanas S/N, C.P. 76010, Querétaro, Qro., México. fernando.garcia@uaq.mx (FGT)

${ }^{2}$ Centro Interdisciplinario de Investigaciones y Estudios sobre Medio Ambiente y Desarrollo (CIIEMAD), Instituto Politécnico Nacional, Calle 30 de Junio de 1520 s/n, Barrio la Laguna Ticomán, C.P. 07340, Delegación Gustavo A. Madero, México, D.F. pedro_joaquin_gutierrez@yahoo.com.mx
} 


\section{Introduction}

Ecologically, Mexico is considered the fourth most diverse country in the world, due to diverse and numerous animal and plant species. It is also among the top five countries in terms of the number of endemic species (CONABIO, 2006). It is among the top five countries in terms of fish species diversity, with 506 species (many endemic) grouped into 47 strictly freshwater families, representing $6 \%$ of the global ichthyofauna (De la Vega-Salazar, 2003). Despite this, there have been few efforts to understand the biology and ecology of this kind of fauna, especially regarding species that currently have no commercial value (Sarukhán, 2009). The State of Querétaro does not have many aquatic systems; however, it does possess ecologically interesting ichthyofauna (LermaChapala-Santiago and Panuco), with 36 species belonging to 12 families (Padilla-García \& Pineda, 1997). Of these, only five species are protected by NOM-059-ECOL-2011 (Ictiobus bubalus, Cichlasoma labridens, Cichlasoma steindachneri, Ictalurus mexicanus, and Ictalurus australis).

Godeidae is a diversified and small family of cyprinodontoid fish, confined to the central plateau of Mexico where its dispersion center lies in the well-isolated Lerma basin (Uyeno et al., 1983). Four species of the Godeidae family have been reported in Querétaro: three species are distributed widely in the Lerma basin (Goodea atripinis, Xenotoca variata, Goodea gracilis), and one species (G. multiradiatus) can only be found in one body of water in the municipality of Amealco (De la Vega-Salazar, 2006; Díaz- Pardo et al., 1993). Girardinichthys multiradiatus has no commercial value, but its importance lies in being and endemic freshwater fish with a distinctive sexual dimorphism, peculiar courtship rituals, and viviparity (Macias, 1994). Scientific knowledge about it focuses on taxanomic aspects (Álvarez del Villar, 1970; Miller \& Fitzsimmons, 1971), ethology (Uyeno et al., 1983), biology (Macias-Garcia \& Burt de Perea, 2002), and trophic ecology (Trujillo-Jiménez \& Viveros, 2006). Despite its importance, there are few studies that address aspects of their ecology and physiology. The aim of this study is to determine the ecophysiological responses of G. multiradiatus to its environmental management.

Hydrological variations cause changes on environmental factors and affect the physiology of fish, particularly, stream flow alteration by dams, water diversions, and urbanization have altered ecological process as well as the distribution of aquatic biota (Filippo Gonzalez Neves dos Santos, 2004). Fish respond to the environmental changes by modifying their behavior and their internal functions, while still having a preference for specific types of habitats (Matthews, 1998). Thus, the ecophysiological basis for the conservation of a species should take into consideration the physiological characteristics and ecological role of the organism in question. Physiological analysis will reflect the conditions which affect population characteristics, such as population growth, intraspecific competition, and functional and numerical responses (Bunn \& Arthington, 2002; De'ath \& Fabricius,
2000; Freeman et al., 2001; Poff et al., 2003). These studies can do more than being simply descriptive, since they enable the development of scenarios that can be tested either through strictly controlled laboratory experiments or field experiments (Phillipson, 1975; Jobling, 1994).

\section{Material and Methods}

Study area. The experiment took place on San Martín Dam, located at $60 \mathrm{~km}$ south of Queretaro city, near to Amealco municipality $\left(100^{\circ} 09^{\prime} 43^{\prime \prime} \mathrm{W} 20^{\circ} 15^{\prime} 02^{\prime \prime} \mathrm{N}\right)$, at 2600 meters above sea level (Fig. 1). The climate is subhumid with summer rains (Cw1) with an average temperature of $15.1^{\circ} \mathrm{C}$, the months of May and June are those with the highest temperatures. The average annual rainfall is $659.5 \mathrm{~mm}$, occurring mainly during the summer (García, 1988). The main contribution to the dam water is from rain. Sampling was made over a full hydrological cycle (one year, beginning in February) in which the $G$. multiradiatus population was monitored once every two months, at the same time physical factors were measure $\left(\mathrm{T}^{\circ}\right.$, $\mathrm{pH}$, dissolved $\mathrm{O}_{2}$, turbidity, depth). The theoretical sampling framework selected took into account the entire population is found within the study area, and longitudinal sampling was conducted by stratifying the same area. To assess the daily feeding activity of the G. multiraditus in San Martín Dam samples were collected with spoon nets every four hours during a period of 24 hours (10:00, 14:00, 18:00, 22:00, $02: 00$ and, 06:00 hours). These catches allowed determining the feeding ecology of the species (feeding time, type of diet at different times of day, food components). The relative density in activity was measured using the catch per unit effort method (CPUE) based on the number of individuals caught by dragging. The fish were fixed in $70 \%$ alcohol and then transported to the laboratory (Nielsen et al., 1983).

Population dynamic. The measurements taken in the laboratory were those of wet weight (Ww), sex and morphometric data of fish: total length (TL), standard length (SL) head length (HL),

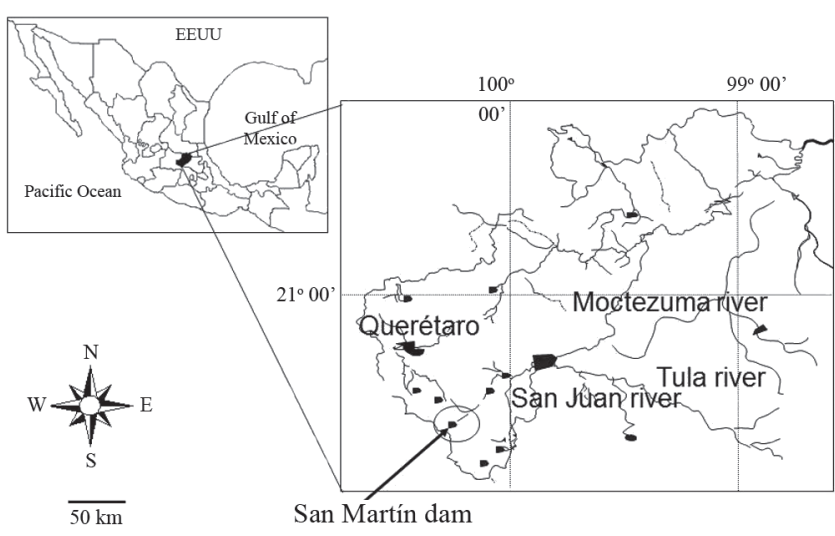

Fig. 1. Environmental parameters during a hydrological cycle in San Martín Dam. 
maximum height (Hmax), and minimum height (Hmin). The minimum sample size was determined using the method described by Gutiérrez-Yurrita (1999).The population structure was determined using the Schnute amended the method of Cassie (1954), which uses probability paper to determine the bimodal or polymodal frequency distribution of size with statistical confidence belts for each class. The population growth was modelled by Holden (1995) a modified version of the von Bertalanffy growth equation which quantifies the seasonal variation in growth rates in a cycle:

$$
L(t)=L_{\infty} e^{-[K(t-t o)+S \sin 2 \pi(t-t s)-S \sin 2 \pi(t o-t s)]}
$$

where $L(\mathrm{t})=$ length; $L_{00}=$ Maximum length; $K=$ growth rate; $\mathrm{S} \sin 2 \pi=$ oscillation; $t=$ time; $t_{0}=$ intercept $t s=$ oscillation time.

This model was considered the most suitable for the study of $G$. multiradiatus, besides the program analysis of length frequency distribution (LFDA) can work with the routine ELEFAN mathematical method (electronic frequency analysis).

Trophic spectrum. The fish alimentary tracts were dissected from the mouth to anus. Empty tracts were not considered in further analysis. Animal prey remains were identified to the lowest readily recognizable taxon, counted and classify into food categories using a stereomicroscope (Hyslop, 1980). In order to determine the food resources several benthic samples, one every catch, were taken at $5 \mathrm{~m}$ intervals around the dam. By using this information the Herrera index which is based on analysis of presence-absence and was calculated applying the next equation:

$$
D=-\sum_{i=1}^{s} \log p i
$$

Where $p i$ is the frequency of occurrence of different food components. This index considers all food components are equally likely to be found in individuals of the sample, $\mathrm{N}$.

The frequency of occurrence defined as the proportion of fish containing given prey category $(\% \mathrm{~F})$ and relative abundance, number of given prey category in relation to total number of preys $(\% \mathrm{~N})$ were quantified (Herrera, 1976). Data collected from three different categories of fish belonging to three size classes were used in a fixed effects factorial analysis with sex as a covariable; the experiments were performed in triplicate.

Bioenergetics. To quantify the aerobic metabolism and nitrogen excretion, animals were placed in a semi closed system with $(0.5 \mathrm{~L})$ respirometric chambers, using a method which assumes that the reduction of oxygen and the increase of nitrogen in the chamber depend on the weight of the animal, the volume of water, the period of time in which no water circulated in the chamber and the ambient temperature (Steffensen, 1989). After each cycle, sample was oven-dried in an electric oven between $70-80^{\circ} \mathrm{C}$ until the samples had constant weight (two weeks after). From each composite sample $2 \mathrm{~g}$ were measured and taken as analytical sample; the samples were digested with concentrated nitric acid. The determination of the percentage proximate composition was chemically analyzed according to the method of analysis described by the Association of Official Analytical Chemist (AOAC, 1998). While other $2 \mathrm{~g}$ sample tissue were combusted in a Parr bomb calorimeter to obtain oxycalorific measurements. The flow of energy that was used to determine the energy efficiency and assimilation is show in the next equation:

$$
C=P+G+E_{R}+E_{U}+F
$$

where $\mathrm{C}$ is the total energy content of food consumed, $P$ and $G$ are the energy equivalents of somatic and gonadal growth respectively, $E_{R}$ is the energy utilized in respiration, $E_{U}$ is the energy lost as nitrogenous and other waste compounds excreted in the urine, and $F$ is the unabsorbed energy voided with the faeces (Bolduc et al., 2002; Bradshaw, 2003). All variables expressed in calories per gram of dry weight (cal/g). The ratio used to transform measured aerobic metabolism into calories was the standard oxycaloric coefficient for fish which mainly excrete $\mathrm{N}_{-} \mathrm{NH}_{4}(\mathrm{Qox}=3.20$ cal mg-1 $\mathrm{O}_{2}$ ). Nitrogen excretion was estimated using literary references, taking into consideration the type of fish, size, feeding habits, and physiological status (Klekowsky Duncan, 1975).

\section{Results}

The physicochemical parameters of water showed stable behavior during the studied hydrological cycle ( $\mathrm{pH}=7$ to 9 ; dissolved oxygen $=7$ to $10 \mathrm{ppm}$ ). On the other hand, the temperature showed significant variation, with the highest temperatures $\left(20-25^{\circ} \mathrm{C}\right)$ recorded between April and August, with the lowest $\left(10-18^{\circ} \mathrm{C}\right)$ recorded between October to February (Fig. 2). Also, due to seasonal differences in water usage, the water level of the dam was low from April to August and high from October to March (Fig. 3).

Relative density in activity, obtained by the catch per unit effort method (CPUE), reaches its maximum values during night, and minimum values were observed during the day (Fig. 4). The minimum population size of the mexcalpique was observed in April, but gradually increased peaking maximum

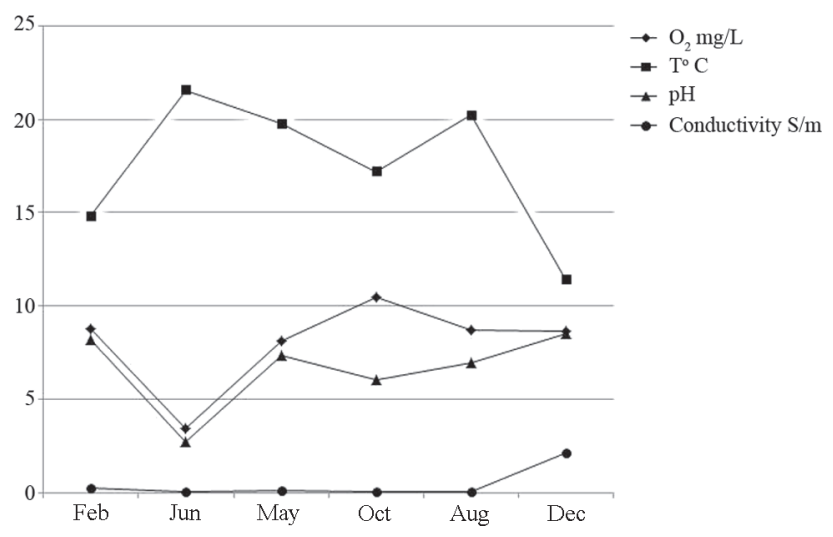

Fig. 2. Ombrothermic diagram for San Martin dam, Amealco, Qro. It shows hydrological periods of importance to the life cycle of mexcalpique. 


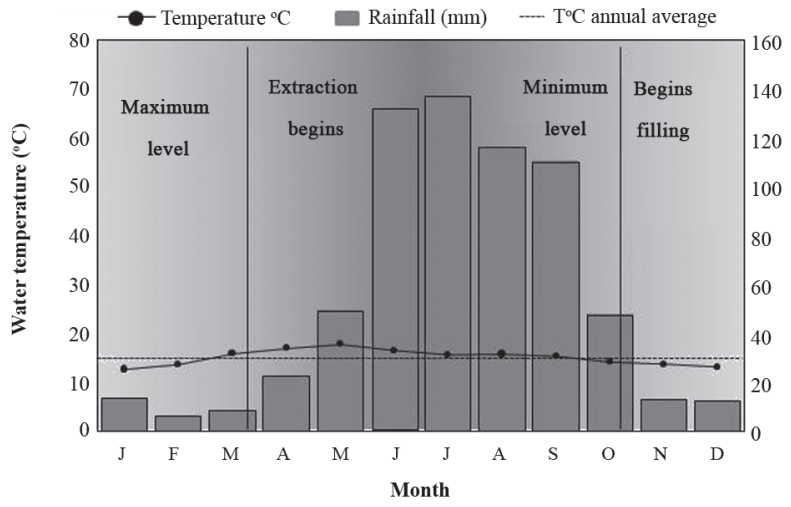

Fig. 3. Catch per unit effort values during a sampling 24 hours.

in October. After that, the density of individuals declined once again. The average biomass (wet weight) of individuals peaked in August (Fig. 5).

According to the Cassie method, the population of $G$. multiradiatus consists of 12 classes, ranging from 8 to $48 \mathrm{~mm}$ standard length. Figure 6 shows the general structure of the mexcalpique population of San Martín. The numbers in parentheses indicate the percentage of each size class of the total population obtained through a year. Two of these size classes were found only in laboratory studies due to their small sizes; these sizes were smaller than what the nets in situ could catch.

The figure 7 shows the bimonthly structure of the population of G. multiradiatus in San Martín and the seasonal pattern of population growth, demonstrated in Von Bertalanffy equation with $L_{00}=47 ; K=0.8870$ and, $t_{0}=-0.2103$. The variations throughout the year are present in both, in the structure of the population and its growth rate, with the shorter pattern cohorts having a higher growth rate and no increase in length during the period of February to June.

From 1022 stomachs analyzed, (1022), 18 food components were identified. The most abundant component found were

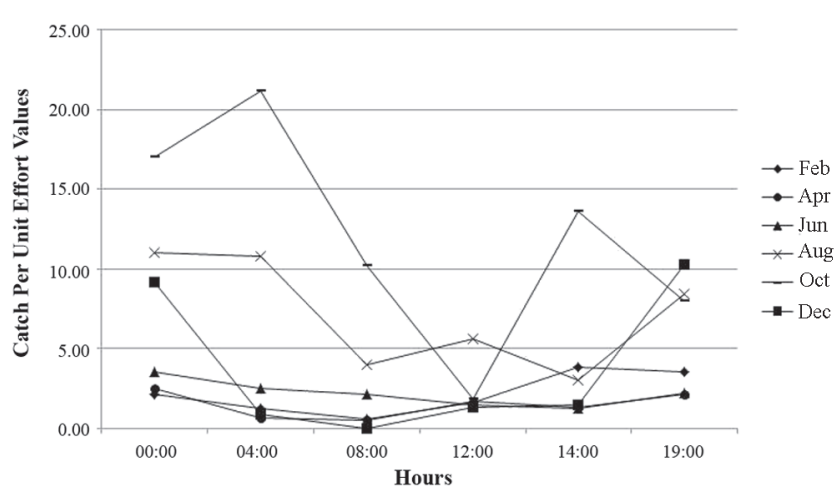

Fig. 4. Number of individuals (bars) and mean biomass of the population (line curve) of mexcalpiques during a hydrological cycle.

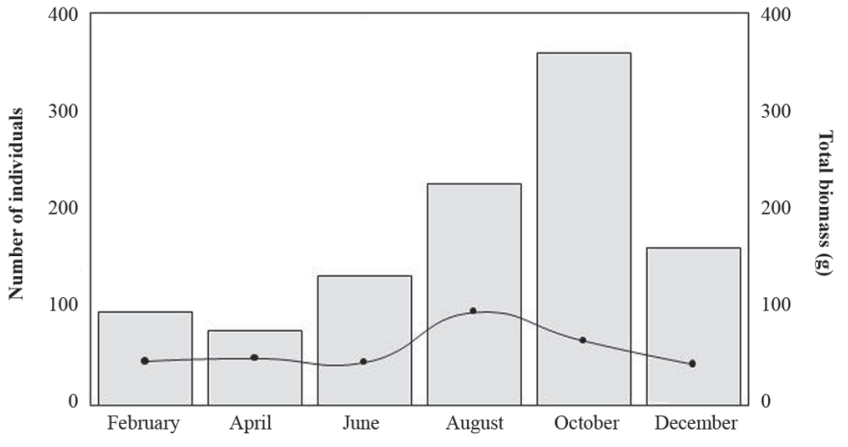

Fig. 5. General structure of the population of San Martín mexcalpique. The numbers in parentheses indicate the percentage of each size class of the total population.

insects (47\%), especially the Diptera order, followed by detritus $(24.0 \%)$ and Cladocera $(17.5 \%)$, with the remaining components accounting for $10.7 \%$. Unusual food components (less than $10 \%$ of the total), were only found at a specific times of the hydrological cycle (Fig. 8). The benthic review showed 20 components and trophic index was calculated indicating that G. multiradiatus is a polytrophic specie $(\mathrm{H} \neq 0)$. The maximum number of categories found in their stomachs were eight while minimum was two. The frequency of occurrence is showed in Table 1. Circadian sampling showed that this specie is polytrophic with two daily feeding periods (5:00 to 8:00 and 14:00 to 18:00 hours).

Physiological experiments showed higher energy expenditures in August with values of $2500 \mathrm{cal} / \mathrm{g}$ and minimal values for December with $200 \mathrm{cal} / \mathrm{g}$. The increased energy expenditure was found in the early hours of the day (daylight hours) and then declined, reaching minimum values at night, with the exception of October, which displayed an inverse pattern (Fig. 9). Calorimetric analysis did not show statistically significant difference between the energy provided by sex ( $p>0.05$ ). Main food energy intake was $4.8 \pm 0.3 \mathrm{Kcal} \mathrm{g}^{-1}$ of

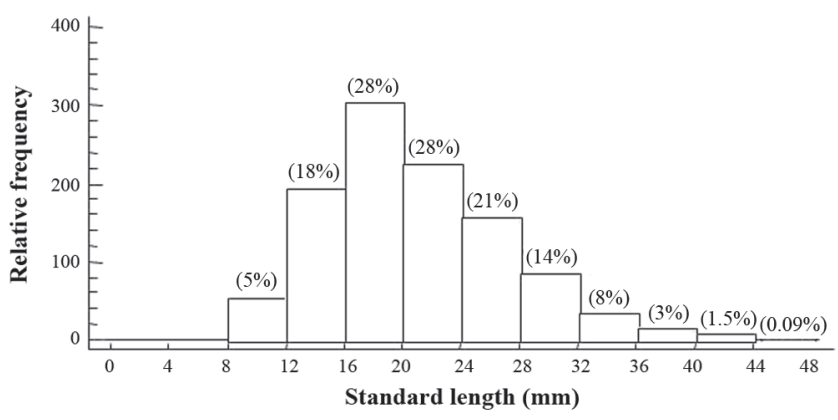

Fig. 6. Bimonthly structure of the population of $G$. multiradiatus in San Martin. Shows the curves of growth with the von Bertalanffy model for highly seasonal cycles. Upon reaching the asymptotic curve determines the final class of each age cohort. 


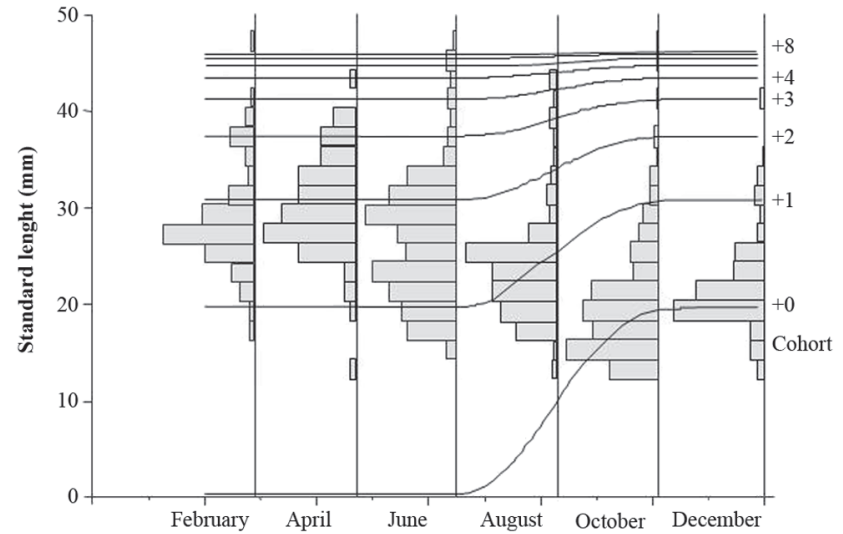

Fig. 7. Bimonthly energy expenditure during cycles of mexcalpique nictemeral in San Martin.

dry weight, with the total weight of the mexcalpique consisting of, on average, $85.49 \pm 2.49 \%$ organic matter, and $14.50 \pm 2.49 \%$ mineral matter. By replacing the caloric values in the energy balance equation, was determined that $G$. multiradiatus uses approximately $81 \%$ of the energy consumed in the production of tissue and gametes (P and $\mathrm{G})$, respiration process spent $5.7 \%\left(\mathrm{E}_{\mathrm{R}}\right)$ and the rest $13.3 \%$ is invested in maintenance $\left(\mathrm{E}_{\mathrm{U}}\right.$ and $\left.\mathrm{F}\right)$. Multivariate analysis of environmental factors on the metabolism, showed no significant differences, however the temperature showed the lowest value of significance $(p=0.08)$.

\section{Discussion}

The management of the level in San Martín Dam influences the population dynamics and physiology of mexcalpique Girardinichthys multiradiatus. The dam's main purpose is to provide irrigation for crops during the dry seasons, causing

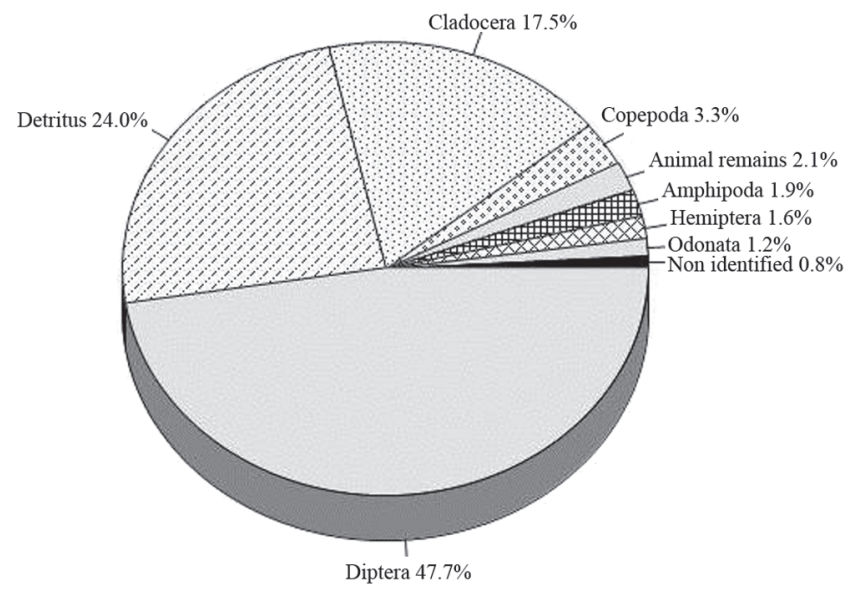

Fig. 8. Percentages of each food components found in the digestive tract of G. multiradiatus during a hydrological cycle in san Martín dam.
Table 1. Occurrence of food components ( $\mathrm{N}=$ number sampled; $\mathrm{n}=$ number of organisms that have the category, 5 occurrence rate) by sex.

\begin{tabular}{|c|c|c|c|c|c|c|}
\hline \multirow[t]{2}{*}{ Category } & \multicolumn{2}{|c|}{$\begin{array}{c}\text { Youth } \\
\mathrm{N}=654\end{array}$} & \multicolumn{2}{|c|}{$\begin{array}{c}\text { Males } \\
\mathrm{N}=195\end{array}$} & \multicolumn{2}{|c|}{$\begin{array}{l}\text { Females } \\
\mathrm{N}=173\end{array}$} \\
\hline & $\mathrm{n}$ & $\%$ & $\mathrm{n}$ & $\%$ & $\mathrm{n}$ & $\%$ \\
\hline Detritus & 230 & 16.08 & 141 & 37.03 & 127 & 38.49 \\
\hline Diptera & 517 & 55.31 & 146 & 34.32 & 142 & 34.41 \\
\hline Cladocera & 231 & 21.5 & 51 & 13.73 & 38 & 13.73 \\
\hline Copepoda & 53 & 3.78 & 25 & 2.26 & 31 & 2.26 \\
\hline Animal remains & 41 & 1.27 & 29 & 2.56 & 47 & 2.56 \\
\hline Amphipoda & 20 & 0.67 & 27 & 3.1 & 34 & 3.01 \\
\hline Hemiptera & 16 & 0.52 & 27 & 2.96 & 38 & 2.96 \\
\hline Odonata & 13 & 0.38 & 21 & 3.21 & 28 & 3.21 \\
\hline Hymenoptera & 1 & 0.06 & 4 & 0.11 & 12 & 0.66 \\
\hline Coleoptera & 0 & 0 & 2 & 0.04 & 6 & 0.6 \\
\hline Crustacea & 1 & 0.004 & 4 & 0.41 & 4 & 0.14 \\
\hline Ephemeroptera & 3 & 0.06 & 0 & 0 & 5 & 0.38 \\
\hline Gasteropoda & 3 & 0.05 & 1 & 0.02 & 6 & 0.17 \\
\hline Plecoptera & 3 & 0.03 & 2 & 0.11 & 0 & 0 \\
\hline Trichoptera & 0 & 0 & 1 & 0.1 & 0 & 0 \\
\hline Homoptera & 0 & 0 & 1 & 0.05 & 0 & 0 \\
\hline
\end{tabular}

major changes in water level. In April, a significant decrease in water level was observed, immediately after the removal of water for irrigation causing a significant population biomass decrease (Fig. 5). Such a change in the water level implies a reduction in habitat size, which forces the fish to relocate within the dam and increases intraspecific competition for resources, mainly space and food, thus, water use directly influences the population size of mexcalpique. The effect of this fact was found by Beam (1983), relating an increase in the water level to the relative year-class strengths of white crappie during a 5-year period. Interestingly, perhaps the greatest threat to the mexcalpique is the uncontrolled use of water from the dam.

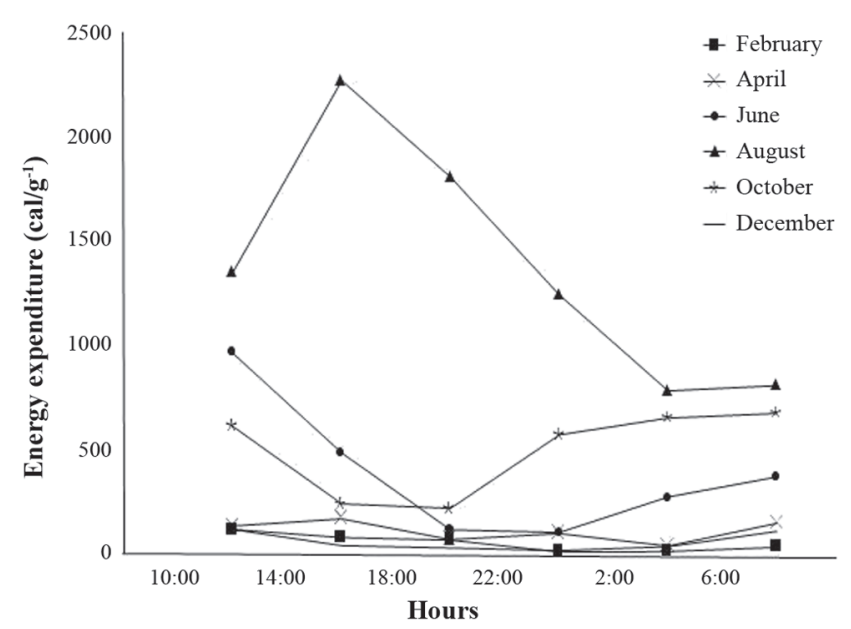

Fig. 9. Bimonthly energy expenditure during cycles of mexcalpique nictemeral in San Martin 
In San Martín Dam the size classes most affected by this sudden change (those populated by juvenile fish) are those with less swim capacity, being displaced from the most benign areas. Figure 6 shows the growth curves behave (for the modal frequencies) during the most significant changes in the hydrological regimen of the system. This could be explained by the fact that, after opening the gate, the fish swim to the newly formed creek, disappearing into the farmland.

It has been shown that environmental factors, mainly temperature, have effects on the survival, growth and reproduction of fish, resulting in changes in population abundance and population weight (Beam, 1983). Similarly, Hepher \& Pruginin (1985) showed that the greatest influences on growth are endogenous (physiological state of animal, age, metabolism), but that environmental factors with greatest influence are temperature, chemical composition and level of metabolites in water, in addition to the quality and abundance of food available. In accordance with these authors, G. multiradiatus showed an increase in relative abundance along a hydrological cycle, while its average biomass showed an inverse behavior. Trophic aspects showed that G. multiradiatus is politrophic species with a higher trend to carnivorism, aspects which allow it to populate diverse habitats, ranging from the Zempoala Lagoon (Macias, 1994) to the San Martín Dam (as in this case). According to the results of the stomach analyses, $G$. multiradiatus is an occasional polytrophic species which tends to be carnivorous (with diurnal habits) and fully exploits seasonal variations in the composition of phytoplankton and zooplankton to enrich its diet. Trujillo \& Viveros (2006) classified G. multiradiatus as a predator, due to the results of their research, which showed that its main diet consisted of chironomids, mayflies and Hymenoptera. However, this work only analyzed 97 stomachs collected from three samplings. In the stomachal analysis, plant components were found (remains of vegetable matter, algae and grass), consistent with the results reported by Macias (1994). However, animals maintained in captivity have displayed no signs of herbivory, suggesting that the ingestion of these components was accidental and consumed while hunting for zooplankton. Alternatively, the algae may have instead been ingested by Diptera which was then, in turn, preyed upon by G. multiradiatus. With these results, we strongly propose that G. multiradiatus is a carnivorous species with a preference for Diptera. However our results suggest the need to investigate more in the trophic aspects such as age, sex and season variation.

Girardinichthys multiradiatus can be considered an efficient species in energy transformation, with the estimated production obtained consistent with the estimates obtained in other studies. Espina et al. (1988) obtained a yield of $75 \%$ for adult white fish Chirostoma estor (classified as an efficient energy transformer), while Gutiérrez-Yurrita \& Latournerié-Cervera (2006), compared three diets of the rainbow trout Salmo gardnieri, concluding a yield of $80 \%$, close to the value estimated in this study. Although nitrogen excretion and defecation could not be estimated directly, we estimated it by using a statistical inference that was based on other parameters of energy flow, that nitrogen excretion and defecation accounts for approximately $16 \%$ of the total energy expenditure. This agrees with the energy estimates of Wineget (1960), who stated that $15 \%$ of the total energy consumed is wasted as feces, and a maximum of $3 \%$ is lost in nitrogenous excretion. Elliot (1976) mentions that the energy loss in the trout Salmo trutta ranged from 4 to $12 \%$ at a temperature of $20^{\circ} \mathrm{C}$, with a 25 to $30 \%$ energy loss observed at the majority of temperatures found in situ. In the case of G. multiradiatus, since the maximum temperature observed was $20^{\circ} \mathrm{C}$, we can consider that energy loss through excretion does not exceed $12 \%$, which agrees with the works of Espina et al. (1960) and Gutiérrez-Yurrita (1988) The assimilation efficiency $(\mathrm{P}+\mathrm{R}>85 \%)$ of $G$. multiradiatus is also among the highest for fish in natural environments. Finally, $G$. multiradiatus great potential as an aquaculture specie, as it both feeds and breeds easily in captivity without losing energy efficiency.

\section{Acknowledgments}

We specially thank to Roxana Fitch, Adriana Medellin and Mario Rodriguez Garcia, for their comments and help with the edition of this article. This work was partially financed by Fondo de Investigación de la Facultad de Ingeniería (FIFI 2011) and CONACYT for awarding the scholarship 48329/ 48329 for doctoral studies.

\section{Literature Cited}

Álvarez del Villar, J. 1970. Peces Mexicanos (Claves). CNCd, Ed. Instituto Nacional de Investigaciones en Biología Pesquera Mexico, 166p.

AOAC, 1998. Official Methods of Analysis of AOAC International, sixteen ed. AOAC, Gaithersburg, MD, USA.

Beam, J. H. 1983. The effect of annual water level management on population trends of White crappie in elk city reservoir, Kansas. North American Journal of Fisheries Management, 3: 34-40.

Bolduc, M., S. Lamarre \& P. Rioux. 2002. A simple and inexpensive apparatus for measuring fish metabolism. Advances in Physiology Education, 2: 129-132.

Bradshaw, S. D. 2003. Vertebrate ecophysiology: An introduction to its principles and applications. United kingdom: Cambridge University Press.

Bunn, S. E. \& A. Arthington. 2002. Basic principles and ecological consequences of altered flow regimes for aquatic biodiversity. Environmental Management, 30: 492-507.

Cassie, R. M. 1954. Some uses of probability paper in the analysis of size frequency distribution. Australian Journal of Marine \& Freshwater Research, 5: 513-522.

CONABIO. 2006. Capital natural y bienestar social. Comisión Nacional para el Conocimiento y Uso de la Biodiversidad, México, 70p.

De la Vega-Salazar, M. Y. 2003. Situación de los peces dulceacuícolas en México. Revista Ciencias, 72: 20-30.

De la Vega-Salazar, M. Y. 2006. Estado de conservación de los peces de la familia Goodeidae (Cyprinodontiformes) en la mesa central de México. Revista Biología Tropical, 54: 163-177. 
De'ath, G. \& Fabricius, K. E. 2000. Classification and regression trees: a powerful yet simple technique for ecological data analysis. Ecology, 81: 3178-3192.

Díaz-Pardo, E., M. A. Godínez-Rodríguez, E. López-López \& E. Soto-Galera. 1993. Ecología de los peces de la cuenca del río Lerma, México. Anales Escuela Nacional Ciencias Biológicas, 38: 103-127.

Elliot, J. M. 1976. Energy losses in the waste products of brown trout (Salmo trutta). Journal Of Animal Ecology, 45: 561-580.

Espina, S., J. Latournerié, A. Sánchez \& M. Vega. 1988. Determinación de los elementos del balance energético en el pescado blanco adulto Chirostoma estor (Pisces: Atherinidae). Anales del Instituto de Ciencias Del Mar y Limnología, 1: 185-194.

Freeman, M., C. H. Zachary, K. D. Bovee \& R. I., Elise. 2001. Flow and habitat effects on juvenile fish abundance in natural and altered flow regimes. Ecological Applications, 11: 179-190.

García, E. 1988. Modificaciones al sistema de clasificación climática de Koppen. México. Enriqueta García.

Gutiérrez-Yurrita, P. J. 1999. Determinación del tamaño mínimo de muestra para el análisis toxicológico de los peces del embalse Zimapan in Querétaro. SSA. Mexico, 5p.

Gutiérrez-Yurrita, P. J. \& J. R. Latournerié-Cervera. 1995. Improvement of the quality of rainbow trout (Oncorhynchus mykiss) and reduction of the operational cost by the use of alternative feed stuff. Pp. 108-109. In: Svennevig, N. Á. Krogdahl (Eds.). Quality in Aquaculture. Belgium: European Aquaculture Society, special publication.

Hepher, B. \& Y. Pruginin. 1985. Cultivo de peces comerciales. Ed. Limusa. México, 316p.

Herrera, C. M. 1976. A trophic diversity index for presence-absence food data. Oecologia, 25: 187-191.

Holden, S., G. Kirkwood \& M. Bravington. 1995. Catch efffort data analysis The CEDA package: user manual.

Hyslop, E. J. 1980. Stomach content analysis: a review of methods and their applications. Journal of Fish Biology, 17: 411-429.

Jobling, M. 1994. Fish Bioenergetics. London: Chapman and Hall.

Klekowsky, R. Z. \& A. Duncan. 1975. Physiological approach to ecological energetics. Pp. 227-261. In: Grodzinski, W., R. Z. Klekowslci \& A. Duncan (Eds). Methods for ecological bioenergetics. Oxford: Blacwell Scientific Publication.

Macias-Garcia, C. \& T. Burt de Perea. 2002. Ultraviole-based female preferences in a viviparous fish Behavioral Ecology and Sociobiology, 52: 1-6.
Macias, G. C. 1994. Social behavior and operational sex ratios in the viviparous fish Girardinichthys multiradiatus. Copeia, 1994: 919-925.

Matthews, W. 1998. Patterns in freshwater fish ecology. USA: Chapman and Hall.

Miller, R. R. \& J. M. Fitzsimmons. 1971. Ameca splendens, a new genus and species of goodeid fish from Western Mexico, with remarks on the classification of the Goodeidae. Copeia, 1971: $1-13$.

Nielsen, L. A., D. L. Johnson \& S. S. Lampton. 1983. Fisheries techniques. Bethesda, Maryland: American Fisheries Society.

Padilla-García, U. \& R. Pineda. 1997. Vertebrados del estado de Querétaro. Querétaro, Mex.: UAQ/FOMES.

Phillipson, J. 1975. Introduction to ecological energetics. Pp. 3-13. In: Grodzinski, W., R. Z. Klekowslci \& A. Duncan (Eds.). Methods for ecological bioenergetics. Oxford: Blacwell Scientific Publication.

Poff, N. L., J. D. Allan \& M. A. Palmer. 2003. River flows and water wars: emerging science for environmental decision making. Frontiers in Ecology and Environment, 1: 298-306.

dos Santos, F. G. N., A., L. N. dos Santos \& F. G. Araujo. 2004. Water level influences on body condition of Geophagus brasilensis (Percoformes: Cichlidae) in Brazilian oligotrophic reservoir. Neotropical Ichthyology, 2: 151-156.

Sarukhán, J. 2009. Capital natural de México. Síntesis: conocimiento actual, evaluación y perspectivas de sustentabilidad. CONABIO (Ed). México.

Steffensen, J. F. 1989. Some errors in respirometry of aquatic breathers: how to avoid and correct for them. Fish Physiology and Biochemistry, 6: 49-59.

Trujillo-Jiménez, P. \& E. E. Viveros. 2006. La ecología alimentaria del pez endémico Girardinichthys multiradiatus (Cyprinidontiformes: Goodeidae), en el Parque Nacional Lagunas de Zempoala, México. Revista de Biología Tropical, 54: 1247-1255.

Uyeno, T., R. Miller \& J. Fitzimons. 1983. Karyology of cyprinodontoid fishes of the Mexican family Goodeidae. Copeia, 1983: 497-510.

Wiegert, R. G. 1960. Ecological energetics. Dowden Hutchinson and Ross, USA.

Wooton, R. 1990. The ecology of the teleost fishes. Chapman and Hall, Great Britain.

Submitted March 20, 2012

Accepted October 24, 2012 by Eliane Gonçalves-de-Freitas

Published March 31, 2013 